\title{
HUMAN RESOURCE DEVELOPMENT AND ECONOMIC GROWTH IN NIGERIA
}

\section{Deinibiteim M. Harry (Ph.D) and Emeh E. Onyinyechika}

\author{
${ }^{1}$ Department of Public Administration, Port Harcourt Polytechnic, Rumuola, Port Harcourt \\ Email: macharryd@gmail.com
}

${ }^{2}$ Institute of Continuing Education, Port Harcourt Polytechnic, Rumuola, Port Harcourt Email: onyimia@gmail.com

Cite this article:

Deinibiteim M.H., Emeh E. O. (2021), Human Resource Development and Economic Growth in Nigeria. African Journal of Economics and Sustainable Development 4(3), 23-49. DOI: 10.52589/AJESD-1EIH4G2X.

\section{Manuscript History}

Received: 14 July 2021

Accepted: 25 Aug 2021

Published: 5 Sept 2021

Copyright $\odot 2020$ The Author(s). This is an Open Access article distributed under the terms of Creative Commons AttributionNonCommercial-NoDerivatives 4.0 International (CC BY-NC-ND 4.0 ), which permits anyone to share, use, reproduce and redistribute in any medium, provided the original author and source are credited.
ABSTRACT: This study examined the impact of human resources development on economic growth in Nigeria from 1980 to 2019. To achieve this objective, data were collected on the real gross domestic product, government expenditure on education, government expenditure on health and human development index from Central Bank of Nigeria Statistical bulletin, World Bank World Development Indicator and UNDP. The study adopted the Augmented Dickey-Fuller unit root test, Johansen Co-integration test and Error Correction Mechanism (ECM) methods of econometric to analyse the collected data. Evidence from the findings revealed that all the variables were individually integrated of Order One and have a long-run relationship. The parsimonious ECM result revealed that an increase in government expenditure on education, government expenditure on health, as well as human development index, do not significantly increase economic growth in Nigeria during the period of study. The study concluded that human resources development via public spending in the education sector, health sector, as well as an increase in human development index remains crucial in the process of achieving sustainable economic growth in Nigeria. Based on these findings, the study recommended among others that crucial effort should be made by the government in channelling more funds to the health sector in order to improve health standards and reduce the mortality rate of the citizens since a healthy population and workforce is a major ingredient for rapid and sustainable productivity and growth. Enough funds should be allocated to education for proper utilization of potential productive and social benefits that will help to boost the real sector of the economy.

KEYWORDS: Human Resources, Health, Education, Government Expenditure, Development. 


\section{INTRODUCTION}

The application of knowledge is a powerful tool in human resource development. The concept of human resource development is unique in the economy; it is an incontrovertible fact that all the factors of production available to any nation, human capital (the citizens has to be healthy and educated to access resources) have the potential and have remained the most important factor of production in the $21^{\text {st }}$ century. Even with the advent of advanced technology like the use of computers and other modern automated machines, this elemental fact has remained unchanged; Human resources are regarded as the stock of competencies, knowledge and personality embodied in the ability to strengthen labour, so as to produce economic value (Adelani, 2017).

It is also an indisputable fact that education has a major role to play in human resource development; education is a veritable tool that all developing and developed nations of the world can use skillfully to accomplish their respective national objectives; therefore, every country attaches greater premium on the viability and sustainability of its education to human resource development. Education plays a vital role in every sector of the economy. The point is that investment in human development is the greatest investment of any nation's economy.

Jhingan (2005), states that in the process of economic growth and development, it is expected to accord main significance to the gathering of physical capital than human capital. These physical resources are from the capital but aside from that, these tangible capital resources are human capital resources as an aggregate of education or schooling, training and healthcare delivery. This aggregation of human resource development can further increase productivity, income, improve health and fitness, good habits in individuals such as being trustworthy, responsible and having integrity etc. Evolving Nigeria human capital development is precarious, especially now that the country is aiming to be among the leading economies in the world today; but this desired ambition will be a venture in futility; if human capital formation is not given due attention with high priority. Human capital formation is a criterion for Nigeria and Nigerians to fit in the 21 st-century globalized economy competition which is highly skilled and knowledge-based. A country's effectiveness in the new international economic order (NIEO) is sturdily associated with her human resource development; hence human capital formation is unique and indisputable the axis for any significant programme of socio-economic development of Nigeria and any country. Therefore, it is very important to the world at large to pay attention to human resource development.

\section{Statement of the Problem}

Nigeria is blessed with different natural resources and in the midst of the wealthy resources, it is still rated as a third world economy. The leaders and the political class have failed in their primary assignment of developing the right persons that will harness the various natural resources in Nigeria. Human capital development hasn't been given due attention yet. Nigeria is acknowledged as one of the most heavily populated countries in Africa with its labour free with large and ample natural resources. Ironically, the nation has witnessed slow economic growth despite the presence of these resources. Observing this occurrence; Udabah (1999-69) stated that the fact that a country is blessed with natural resources does not mean it will do well in terms of growth and also it does not mean a country without natural resources will not excel. It is clear from the statement that human capital development is highly important for the 
African Journal of Economics and Sustainable Development

ISSN: $2689-5080$

Volume 4, Issue 3, 2021 (pp. 23-49)

www.abjournals.org

government to adopt policies that are applicable to the development of human capital investments.

\section{Aims/Objectives of the study}

The aim of this study is to examine the impact of human resources development on economic growth in Nigeria from 1980-2019. Specifically;

i. To examine the impact of government health expenditure on economic growth in Nigeria

ii. To examine the impact of government education expenditure on economic growth in Nigeria

iii. To examine the impact of the human development index on economic growth in Nigeria

\section{Research Hypotheses}

Ho1: Government expenditure on health has no significant impact on economic growth in Nigeria

Ho2: Government expenditure on education has no significant impact on economic growth in Nigeria.

Ho3: Human development index has no significant on economic growth in Nigeria.

\section{Significance of the study}

The study will be profitable to organizations in the area of manpower and training and to the government, especially in the area of policymaking. Generally, it will be helpful for record purposes.

\section{LITERATURE REVIEW}

\section{The Concept of Human Resource}

Harbison (1973) defined human resources development as a deliberate and continuous process of acquiring requisite knowledge, skills and experiences that are applied to produce economic value for driving sustainable national development. The relevance of human resource development in the achievement of meaningful and sustainable economic growth and development has been acknowledged in various studies across the globe. He showed the relevance of human resource development and utilization as follows:

"Human resource; not capital nor income, nor material resources constitutes the ultimate basis for the wealth of nations, capital and natural resources are passive factors of productions, while human beings are the active agent who accumulates capital, exploits natural resources, build a social-political organization and also carry forward national development clarity. Any country that is unable to develop skills and technical know-how for its people and ways to fully maximize them effectively in the country's economy will be unable to actually develop anything else. Jhingan (1996) sees human resource development as a form of investment in 
human beings. To him, it is the way of acquiring and increasing numbers of people who have these skills, education and as well as political development of a country. Human capital formation thus is related to investment in man and his development as a creative and productive resource person.

\section{The Concept of Development}

Development, as a concept, is all-encompassing and reflecting the totality of the wellbeing of individuals, families, society and nation. Thus, it is defined by many scholars from different perspectives. Dudley Seer (1972) sees development as a means of creating the condition for the realization of human personality. He postulated certain criteria for measuring development, that is, whether there has been a reduction in poverty, unemployment and inequality; whether there is improvement in education and demographic characteristics; and whether there is selfreliance and social justice. A country that experiences a downward trend in the above criteria cannot be said to be developed. Development can be seen as an improvement in the reduction of poverty, unemployment, and inequality, improvement in education, demographic characteristics, self-reliance and social justice. Thus, development is achieved when people's needs and aspirations are met, thereby enhancing their wellbeing.

\section{The Concept of Economic Growth}

According to Todaro (1977), economic growth is the steady process by which the productive capacity of the economy is increased over time to bring about rising levels of national income. However, most economists are concerned not only with the absolute increase in the output of goods and services in the economy over time but also how the output per capita increases over time. Thus, Ohale (2002) defined economic growth in two senses. In one sense, the increase in the productive capacity of the economy leading to increased availability of goods and services in the economy over some given period of time. In another sense, as the sustained increase in per capita output of goods and services over a period of time. These two senses do not contradict each other since a persistent increase in the output of goods and services is likely to translate to an increase in per capita output (though this may depend on the rate of growth of the population). Mayer (2010) defined economic growth as a substantial increase in a country's real Gross Domestic Product (GDP) per person over time. To Gbosi (2015), economic growth means the expansion of a country's capability to produce goods and services.

\section{The Theory of Human Capital Investment / Lucas Growth Model}

Lucas Robert (1988) presents a growth model in which output is generated via a production function of the form. He assumes that investment in education leads to the production of human capital which is the crucial determinant in the growth process.

$\mathrm{Y}-\mathrm{Aka}(\mathrm{ihl})^{\mathrm{I}-\mathrm{a}}$

Where $\mathrm{Y}, \mathrm{A}$ and $\mathrm{K}$ are usually defined and $\mathrm{O}<\mathrm{A}<\mathrm{L}$, where $\mathrm{L}$ is defined as the proportion of total labour time spent working and is what Lucas calls the stock of "Human Capital". Before analyzing the model Mankin (1995), has constantly argued by defining "knowledge" as the sum of technological and scientific discoveries (what is written in textbooks, scholarly journals, websites and the like), and defining "human capital" as the stock of knowledge that has been transmitted from those sources into human brains via studying. Lucas model emphasizes that there is an externality to human capital. The idea here is that each person is more productive if 
they are surrounded by other people's capital. The model also shows that this decentralized solution is suboptimal because individual consumers do not obtain the full benefits from society.

The theory was criticized on the ground that human capital can be accumulated without bound and without diminishing returns, in the model, technology is endogenously provided as a side effect of investment decisions made by firms, and technology is treated as a public good from the point of view of its users. As a result, firms can be treated as price takers and there can be equilibrium with many firms as under perfect competition.

A fundamental definition of economic growth is usually in terms of the economy's potential for the production of goods and services. Nevertheless, productive capacity is usually important in the concept of economic growth. Economic growth, however, depends not only on changes in the economy's potential for production but also the extent to which that capacity is utilized. Therefore, economic growth involves an increase over time in the actual output of goods and services as well as an increase in the economy's capability to produce goods and services.

In fact, all countries of the world desire to achieve fast rates of economic growth to raise the standard of living of citizenry, they also desire it because economic growth offers the prospect for the reduction of poverty and it is an important instrument for acquiring power and prestige (Ohale, 2002). Growth occurs when an economy's productive capacity increases which in turn, is used to produce more goods and services. Factors that lead to growth include improvements in the skill and training of the labour force, increase in productivity, i.e., output per hour of work, better management and technology, enlarged excellence and higher excellence of the stock of capital.

Adelakun (2019) examined human capital development and economic growth in Nigeria.

This study shows the relevance of capital development and economic growth in Nigeria by adopting a conceptual analytical framework that employs the theoretical and ordinary least square (OLS) to analyze the relationship using the GDP as a proxy for economic growth, total government expenditure on education and health; and the enrolment pattern on tertiary, secondary and primary schools as a proxy for human capital. The analysis confirms that there is a strong positive relationship between human capital development and economic growth, following the findings, it was recommended that stakeholders need to evolve a more pragmatic means of developing human capabilities since it is seen as an important tool for economic growth in Nigeria. Also, the proper institutional framework should be put in place to look into the manpower needs of the various sectors and implement policies that will lead to the overall growth of the economy.

Emeh and Pepple (2019) examined Education: as a catalyst for human capital development in science and technology in Nigeria over the years with time-series data of 1986-2017 which were sourced from Central Bank statistical bulletin. The variables were tested for unit root via ADF. Johansen cointegration test and ECM were also conducted. The result revealed the existence of a long-run relationship amongst the variables. The result also indicated that human capital development affects the administrative growth of the economy within the study period.

Adenike and Sheriffdeen (2017) examined the interactive effects of the relationship between human capital investment components and economic growth in Nigeria for the period 1986 2014. The study employed secondary annual data on education expenditure, health 
expenditure, real gross domestic product and gross capital formation obtained from the Central Bank Statistical bulletin, 2014. The data were analyzed using the Fully Modified Ordinary Least Squares (FMOLS) technique. The results of the study showed that there was a positive and significant relationship between the interactive effects of human capital components and growth in Nigeria.

Ogunleye, Owolabi, Sanyaolu and Lawal (2017) employed the Ordinary Least Squares regression analysis to examine the impact of human capital development on the economic growth of Nigeria, using annual time series data from 1981 to 2015. The empirical results revealed that human capital development has a significant impact on economic growth, as a proxy by the gross domestic product. In line with theory, the human capital development indicators namely secondary school enrolment, tertiary school enrolment, total government expenditure on health and total government expenditure on education exhibit positive and statistically significant impact on the economic growth of Nigeria which implies that these indicators are indispensable in the achievement of growth in the Nigerian economy. However, life expectancy and primary school enrolment exhibit a negative and statistically insignificant impact on the economic growth of Nigeria.

Jaiyeoba (2015) examined human capital investment and economic growth in Nigeria from 1982 to 2014. The study employed trend analysis, the Johansen Co-integration and Ordinary Least Squares techniques. The findings of the study showed that there is a long-run relationship between government expenditure on education, health and economic growth. The finding also revealed that the study has strong implications in education and health policies, considering the fact that they are of great debate in a country.

Adofu, Abdulsalam and Agama (2015) examined the impact of human capital development on economic growth in Nigeria using simple regression analysis. The outcome revealed that about $91 \%$ of the changes in the dependent variable (GDP) were accounted for by changes in the explanatory variable. This to a large extent explains the place of human capital development in economic growth. The more the government concentrates on human capital development, the more economic progress will be recorded.

The study has shown that investment in human resource development has not yielded the desired impact on the level of growth yet. Investment in human resource development is good but the application after the investment is very important to the development of every sector in the economy. Therefore, further research work should be carried out on the impact of human resources development on unemployment in the country.

\section{METHODOLOGY}

This investigation adopted an ex-post facto research design, which is often applied as a substitute for true experimental research to test hypotheses about cause-and-effect relationships. The study employed augmented Dickey-fuller unit root test, Johansen cointegration test and error correction mechanism method of econometrics. 


\section{Data collection and sources}

Since the research is analytical in nature, the type of data required for this study is secondary data; moreover, the data collected and utilized in this work were from CBN's Statistical Bulletin, World Bank and UNDP. Thus, the data remain secondary in nature

\section{Model Specification}

This section specifies the econometric model that was used in this study. That is, it specifies an econometric model aimed at capturing the impact of human resources development on the economic growth of Nigeria (regress and) proxied by real gross domestic product. Specifically, the model is a theoretical construct representing the economic processes by a set of variables and a set of relationships between them; the model that was used to test the hypotheses stated earlier is a modification of Jaiyeoba(2015). The model for this study is stated below:

$\mathrm{RGDP}=\mathrm{F}(\mathrm{GEE}, \mathrm{GEH}, \mathrm{HDI})$

$\mathrm{RGDP}_{\mathrm{t}}=\mathrm{a}_{\mathrm{o}}+\mathrm{a}_{1} \mathrm{GEE}_{\mathrm{t}}+\mathrm{a}_{2} \mathrm{GEH}+\mathrm{a}_{3} \mathrm{HDI}+\mathrm{u}_{\mathrm{t}}$

Where:

RGDP $=$ Real Gross Domestic Product

GEE = Government Expenditure on Education

$\mathrm{GEH}=$ Government Expenditure on Health

HDI = Human Development Index

$\mathrm{u}=$ Error Term

$\mathrm{a}_{0}=$ the constant parameter

$\mathrm{a}_{1}, \mathrm{a}_{2}$, and $\mathrm{a}_{3}=$ the slope parameters

Apriori expectation: On the apriori: $\mathrm{a}_{1}, \mathrm{a}_{3}, \mathrm{a}_{3}>0$.

\section{DATA PRESENTATION, ANALYSIS}

Research Data on RGDP, GEE, GEH and HDI from 1980-2019.

\begin{tabular}{|c|c|c|c|c|}
\hline YEAR & RGDP(N m) & GEE(N m) & GEH(N m) & HDI \% \\
\hline 1980 & 31546.08 & 1549.8 & 302.5 & 0.41 \\
\hline 1981 & 205222.1 & 984.6 & 248.2 & 0.396 \\
\hline 1982 & 199685.2 & 1134.7 & 286 & 0.356 \\
\hline 1983 & 185598.1 & 966.8 & 279.6 & 0.325 \\
\hline 1984 & 183563.0 & 861.2 & 190.2 & 0.363 \\
\hline 1985 & 201036.3 & 850.2 & 223.9 & 0.391 \\
\hline 1986 & 205971.4 & 1094.8 & 360.4 & 0.393 \\
\hline 1987 & 204804.5 & 653.5 & 236.4 & 0.3802 \\
\hline
\end{tabular}


African Journal of Economics and Sustainable Development

ISSN: 2689-5080

Volume 4, Issue 3, 2021 (pp. 23-49)

www.abjournals.org

\begin{tabular}{|c|c|c|c|c|}
\hline 1988 & 219875.6 & 1084.1 & 443.2 & 0.3705 \\
\hline 1989 & 236729.6 & 1941.8 & 452.6 & 0.378 \\
\hline 1990 & 267550.0 & 2294.3 & 658.1 & 0.438 \\
\hline 1991 & 265379.1 & 1554.2 & 757 & 0.328 \\
\hline 1992 & 271365.5 & 2060.4 & 1025.4 & 0.348 \\
\hline 1993 & 274833.3 & 7999.1 & 2684.5 & 0.389 \\
\hline 1994 & 275450.6 & 10283.8 & 3027.8 & 0.384 \\
\hline 1995 & 281407.4 & 12728.7 & 5060.9 & 0.452 \\
\hline 1996 & 293745.4 & 15351.8 & 4851.5 & 0.393 \\
\hline 1997 & 302022.5 & 15945 & 5803 & 0.456 \\
\hline 1998 & 310890.0 & 26721.3 & 11984.3 & 0.439 \\
\hline 1999 & 312183.5 & 31563.8 & 16180 & 0.455 \\
\hline 2000 & 329178.7 & 67568.1 & 18181.8 & 0.466 \\
\hline 2001 & 356994.3 & 59751.2 & 44651.5 & 0.463 \\
\hline 2002 & 433203.5 & 109455.2 & 63171.2 & 0.445 \\
\hline 2003 & 477533.0 & 79436.1 & 97564.5 & 0.445 \\
\hline 2004 & 527576.0 & 93767.9 & 59787.4 & 0.463 \\
\hline 2005 & 561931.4 & 120035.5 & 71685.4 & 0.466 \\
\hline 2006 & 595821.6 & 165213.7 & 105590 & 0.477 \\
\hline 2007 & 634251.1 & 185771.8 & 122400 & 0.481 \\
\hline 2008 & 672202.6 & 191347.9 & 99891.8 & 0.487 \\
\hline 2009 & 718977.3 & 197088.4 & 109293.9 & 0.492 \\
\hline 2010 & 776332.2 & 203001 & 110528.6 & 0.5 \\
\hline 2011 & 834161.9 & 216805.1 & 106571.4 & 0.507 \\
\hline 2012 & 902794.0 & 401855.4 & 108798 & 0.514 \\
\hline 2013 & 964184.0 & 273887.2 & 108632.7 & 0.521 \\
\hline 2014 & 969969.1 & 297515.9 & 108000.7 & 0.525 \\
\hline 2015 & 990690.7 & 324419.5 & 108477.1 & 0.527 \\
\hline 2016 & 974947.9 & 298607.6 & 108370.2 & 0.529 \\
\hline 2017 & 978535.9 & 306847.7 & 108282.7 & 0.534 \\
\hline 2018 & 981391.5 & 309958.3 & 108376.7 & 0.53 \\
\hline 2019 & 978291.8 & 305137.9 & 108343.2 & 0.531 \\
\hline
\end{tabular}

Source: CBN Statistical Bulletin (Various Issues), World Bank (IBRD)-World Development Indicator and United Nations Development Programme (UNDP)

Note: $R G D P=$ Real Gross Domestic Product, GEE = Government Expenditure on Education, $G E H=$ Government Expenditure on Health, and HDI = Human Development Index. 


\section{Parsimonious Error Correction Model}

Dependent Variable: D(RGDP)

Method: Least Squares

Date: 03/12/20 Time: 16:46

Sample (adjusted): 19842019

Included observations: 36 after adjustments

\begin{tabular}{crrrr}
\hline Variable & Coefficient & Std. Error & t-Statistic & Prob. \\
& & & & \\
\hline C & 7959.825 & 4191.029 & 1.899253 & 0.0679 \\
D(RGDP(-1)) & 0.528735 & 0.178495 & 2.962186 & 0.0062 \\
D(RGDP(-2)) & 0.140320 & 0.193712 & 0.724371 & 0.4748 \\
D(RGDP(-3)) & -0.036200 & 0.085917 & -0.421331 & 0.6767 \\
D(GEE(-3)) & 0.092904 & 0.075398 & 1.232189 & 0.2281 \\
D(GEH(-3)) & 0.113793 & 0.235602 & 0.482986 & 0.6329 \\
D(HDI(-3)) & 57273.04 & 87333.92 & 0.655794 & 0.5173 \\
ECM(-1) & -25233.51 & 13438.78 & -1.877664 & 0.0709
\end{tabular}

R-squared

Adjusted R-squared

S.E. of regression

Sum squared resid

Log-likelihood

F-statistic

Prob(F-statistic)
0.603313 Mean dependent var 22019.27

0.504141 S.D. dependent var 23518.47

16561.06 Akaike info criterion 22.46063

7.68E+09 Schwarz criterion 22.81252

-396.2913 Hannan-Quinn criter. 22.58345

6.083513 Durbin-Watson stat 1.846038

0.000223

\section{Unit Root Test (1980-2019)}

\begin{tabular}{|c|c|c|c|c|c|}
\hline \multirow{2}{*}{$\begin{array}{l}\text { Variabl } \\
\text { es }\end{array}$} & ADF Test & \multicolumn{2}{|c|}{ Critical Values } & \multicolumn{2}{|c|}{$\begin{array}{c}\text { Order of } \\
\text { integration }\end{array}$} \\
\cline { 2 - 6 } & & $\begin{array}{c}\text { critical value } \\
\mathbf{1 \%}\end{array}$ & $\begin{array}{c}\text { critical } \\
\text { value 5\% }\end{array}$ & $\begin{array}{c}\text { Critical value } \\
\mathbf{1 0 \%}\end{array}$ & \\
\hline RGDP & -6.893443 & -3.615588 & -2.941145 & -2.609066 & $1(1)$ \\
\hline GEE & -6.275450 & -3.621023 & -2.943427 & -2.610263 & $1(1)$ \\
\hline GEH & -6.507465 & -3.615588 & -2.941145 & -2.609066 & $1(1)$ \\
\hline HDI & -9.380545 & -3.615588 & -2.941145 & -2.609066 & $1(1)$ \\
\hline
\end{tabular}

Note: RGDP, GEE, GEH, and HDI as earlier defined.

Source: Computed Result Using (E-Views) 
The stationarity test result presented in the Table shows that at various levels of significance $(1 \%, 5 \%$ and $10 \%)$, the variables were not stationary at level. In line with Granger and Newbold (1974), the variables were differenced. Thus, RGDP, GEE, GEH and HDI became stationary at the first difference (i.e., integrated of order one). Hence, the entire variables in this study are stationary. The results of the variables being stationary at first difference make it inappropriate for the application of the Ordinary Least Square (OLS) method, therefore the tests to determine the long-run relationship can be achieved with the aid of the Johansen Co-integration test which is presented in Table.

\section{Test for Co-integration}

Co-integration is conducted based on the test proposed by Johansen. According to Iyoha and Ekanem, (2002) Co-integration deals with the methodology of modelling non-stationary time series variables. For detailed results of the Johansen Co-integration, see the Table.

\section{Johansen Test for Co-integration}

\begin{tabular}{|c|c|c|c|c|}
\hline Eigen value & Trace Statistic & 5\% critical value & Prob. ** & $\begin{array}{l}\text { Hypothesis of } \\
\text { CE(s) }\end{array}$ \\
\hline 0.608559 & 75.28970 & 55.24578 & 0.0003 & None * \\
\hline 0.406333 & 39.64876 & 35.01090 & 0.0149 & At most $1 *$ \\
\hline 0.269912 & 19.83417 & 18.39771 & 0.0313 & At most $2 *$ \\
\hline 0.187274 & 7.879740 & 3.841466 & 0.0050 & At most 3* \\
\hline
\end{tabular}

Source: Computed Result Using (E-Views)

The Table indicates that there are four co- integrating equations because four of the Trace Statistic(s) are larger than the critical value at 5\%. Therefore, there is a long-run relationship among RGDP, GEE, GEH and HDI, which prevent them from wandering apart without bound. Given that there are four co-integrating equations, the requirement for fitting in an Error Correction Model is satisfied. The Error Correction Mechanism (ECM) intends to validate the presence of a long-run relationship and incorporate the short-run dynamics into the long-run equilibrium relationship.

\section{CONCLUSION AND RECOMMENDATIONS}

This study empirically examined the impact of human resources development on economic growth in Nigeria from 1980 to 2019. To achieve this, time-series data were collected from the CBN Statistical Bulletin, World Bank (IBRD) -World Development Indicator and United Nations Development Programmes (UNDP) on variables such as real gross domestic product, government expenditure on education, government expenditure on health and human development index. The researcher applied the Augmented Dickey-Fuller unit root test, Johansen Co-integration test and Error Correction Mechanism (ECM) test based on EngleGranger (1987) co-integration theorem, as well as post estimation test. Evidence from the findings revealed that all the variables were individually integrated of order one and have longrun relationships amongst them. This implies that the variables adopted for the study are collectively significant in explaining changes in economic growth in Nigeria. 
The parsimonious ECM result showed that an increase in government expenditure on education, government expenditure on health, as well as human development index, do not significantly increase economic growth in Nigeria during the period of study. Also, the coefficient of the ECM exhibited the hypothesized negative sign and is statistically significant. The Durbin Watson statistics value suggests that the model has no serial correlation issue and the entire model is statistically significant. Therefore, the model is good for policy recommendations.

\section{Conclusion}

The study on the impact of human resources development on economic growth in Nigeria from 1980 to 2019 is essential. This is because it has brought to the fore the opportunities and benefits inherent in human resources development in the country. This will significantly help policymakers design better policies that will boost economic growth via adequate development of the human resources Nigeria is blessed with. The study utilized data on the real gross domestic product, government expenditure on education, government expenditure on health and human development index from CBN Statistical Bulletin, World Bank (IBRD) -World Development Indicator and United Nations Development Programme (UNDP)covering the period of 1980-2019 and applied the Augmented Dickey-Fuller unit root test, Johansen Cointegration test and Error Correction Mechanism (ECM) methods of econometrics. The findings reveal that increase in government expenditure on education, government expenditure on health, as well as human development index, do not significantly increase economic growth in Nigeria during the period of study.

The study concluded that human resources development via public spending in the education sector, health sector, as well as increase in human development index remains crucial in the process of achieving sustainable economic growth in Nigeria.

\section{Recommendations}

Based on the findings of the study, the following recommendations were suggested:

(i) Crucial effort should be made by the government in channelling more funds to the health sector in order to improve health standards, reduce the mortality rate and hence life expectancy of the citizens since a healthy population and workforce is a major ingredient for rapid and sustainable productivity and growth.

(ii) Enough funds should be allocated to education for proper utilization of potential productive and social benefits that will help to boost the real sector of the economy.

(iii) Government should strengthen and modernize the national skill development/training system (Industrial Training Fund -ITF, and National Directorate of Employment NDE).

\section{Recommendations for Further Studies}

The study has carefully examined the impact of human resources development on economic growth in Nigeria from 1980 to 2019. Therefore, further research work should be carried out on the impact of human resources development on unemployment in Nigeria. 


\section{REFERENCES}

Adelakun, O. J. (2011). Human Capital Development and Economic Growth in Nigeria. European Journal of Business and Management, 3(9), 29-38.

Adenike, M. O. \& Sheriffdeen, A. T. (2017).Human Capital Variables and Economic Growth in Nigeria: An Interactive Effect. Euro Economica, Vol 36, No 1 (2017).

Adofu, I., Abdulsalam, J. \& Agama, J. E. (2015).Human Capital Development and Economic Growth in Nigeria. International Journal of Philosophy and Social-Psychological Sciences, 1(1), 22-27.

Baridam, D. M. (2012).Research Method in Administrative Sciences. Port Harcourt: Paragraphic publishers.

Becker, G.S. (1993). Human Capital: A theoretical and Empirical Analysis with special reference to education Chicago, University of Chicago.

Cookey, A. E. (1998). Research Methods for Business and Economics Students. Abbot books Ltd. Onisha.

Dickey, D.A. and Fuller, W.A. (1979). Distribution of the estimates for Autoregregressive time series with a unit root. Journal of the American Statistical Association Vol. 74, No. 366, pp. $427-431$.

Dicky and Fuller Augmented Dickey fuller test- Maltais daftest MathWorks. Com 2017-1115

Eigbiremolen, G. O. \& Anaduaka, U. S. (2014). Human Capital Development and Economic Growth: The Nigeria Experience. International Journal of Academic Research in Business and Social Sciences, 4(4), 25-35.

Emeh, E. Onyinyechika \& People Adoye E. Education: A catalyst for Human Capital Development, in Science and Technology.International Journal of Development and Economic sustainability Vol. 7 No 7, Pp 25-38 December 2019 Published by ECRTDUK.

Gbosi, N. G (2015) Contemporary macroeconomic problems and stabilization policies, spirit and truth Publishers, Benin City Nigeria.

Gujarati, D. N. \& Sangeetha (2007). Basic Econometric. Tata McGraw-Hill Publishing Company Ltd. Delhi.

Iyoha, M. A. and Ekanem, O. T. (2002).Introductory Econometrics. Benin City: Mareh Publishers.

Jaiyeoba, S.V. (2015). Human capital investment and economic growth in Nigeria. International multidisciplinary Journal, Ethiopia Vol. 9, No.1

Jhingan, M.L. (2005). The economics of development and planning. New Delhi Nirade publisher $38^{\text {th }}$ edition LTD. India.

Ogunleye, O. O., Owolabi, O. A., Sanyaolu, O. A. \& Lawal, O. O. (2017).Human Capital Development and Economic Growth in Nigeria. IJRDO-Journal of Business Management, 3(8), 17-37.

Ohale, L. \& Onyema, J. I (2002) Foundations of Macroeconomics, spring-field, Publishers, Nigeria.

Todaro, M. P \& Smith, S. C. (1977) Economic Development, Eleventh Edition. Pearson Education Limited Edinburg, Grate Harlow, England.

Udabah, S.I. (1999). Basic economics theory and practice Enugu, Linco Press Nigeria Limited 
Udeorah, S. A., Obayori, J. B. and Onuchuku, O. (2018).Health Care Expenditure and Economic Growth in Nigeria. International Journal of Research and Innovation in Social Science (IJRISS), 2(3): 33-36.

UNDP (1999). Human development report New York Oxford University Press.

Urhie E. (2014) Public Education Expenditure and Economic Growth in Nigeria: A Disaggregated Approach. Journal of Empirical Economics, 3(6): 370-382.

World Health Organization (2005). World Health development indicators Washington D.C.

Wu, S.Y., Tang, J.H and Lim, E.S. (2010). The Impact of government expenditure on economic growth". How sensitive to the level of development? Journal of policy modelling PP. 804-817. 


\section{APPENDIX}

\section{UNIT ROOT TEST RESULTS}

\section{RGDP @ LEVEL}

Null Hypothesis: RGDP has a unit root

Exogenous: Constant

Lag Length: 1 (Automatic - based on SIC, maxlag=9)

\section{t-Statistic Prob.*}

\begin{tabular}{cccc} 
Augmented Dickey-Fuller test statistic & 1.306059 & 0.9982 \\
\hline Test critical values: & 1\% level & -3.615588 & \\
& 5\% level & -2.941145 & \\
& 10\% level & -2.609066 &
\end{tabular}

*MacKinnon (1996) one-sided p-values.

Augmented Dickey-Fuller Test Equation

Dependent Variable: D(RGDP)

Method: Least Squares

Date: 03/12/20 Time: $16: 34$

Sample (adjusted): 19822019

Included observations: 38 after adjustments

\begin{tabular}{lrlll}
\hline \multicolumn{1}{c}{ Variable } & Coefficient & Std. Error & t-Statistic & Prob. \\
& & & & \\
\hline & & & & \\
RGDP(-1) & 0.016871 & 0.012918 & 1.306059 & 0.2001 \\
D(RGDP(-1)) & 0.225592 & 0.109412 & 2.061857 & 0.0467 \\
C & 6545.530 & 7399.789 & 0.884556 & 0.3824 \\
& & & & \\
\hline & & & \\
R-squared & 0.165123 & Mean dependent var & 20343.94 \\
Adjusted R-squared & 0.117416 & S.D. dependent var & 24001.97 \\
S.E. of regression & 22548.88 & Akaike info criterion & 22.96042 \\
Sum squared resid & $1.78 E+10$ & Schwarz criterion & 23.08970 \\
Log-likelihood & -433.2479 & Hannan-Quinn criter. & 23.00641 \\
F-statistic & 3.461169 & Durbin-Watson stat & 0.871557 \\
Prob(F-statistic) & 0.042501 & & \\
& & & \\
\hline
\end{tabular}


African Journal of Economics and Sustainable Development

ISSN: 2689-5080

Volume 4, Issue 3, 2021 (pp. 23-49)

\section{RGDP @ 1 ${ }^{\mathrm{ST}}$ DIFF.}

Null Hypothesis: D(RGDP) has a unit root

Exogenous: Constant

Lag Length: 0 (Automatic - based on SIC, maxlag=9)

\section{t-Statistic Prob.*}

Augmented Dickey-Fuller test statistic $\begin{array}{ll}-6.893443 & 0.0000\end{array}$

Test critical values:

$1 \%$ level

$-3.615588$

$5 \%$ level

$-2.941145$

$10 \%$ level

$-2.609066$

*MacKinnon (1996) one-sided p-values.

Augmented Dickey-Fuller Test Equation

Dependent Variable: D(RGDP,2)

Method: Least Squares

Date: 03/12/20 Time: $16: 35$

Sample (adjusted): 19822019

Included observations: 38 after adjustments

\begin{tabular}{lrlll}
\hline \multicolumn{1}{c}{ Variable } & Coefficient & Std. Error & t-Statistic & Prob. \\
& & & & \\
\hline \multicolumn{1}{c}{ D(RGDP(-1)) } & -0.752941 & 0.109226 & -6.893443 & 0.0000 \\
\multicolumn{1}{c}{ C } & 14168.47 & 4593.106 & 3.084726 & 0.0039 \\
& & & & \\
\hline & & & \\
R-squared & 0.568963 & Mean dependent var & -4651.993 \\
Adjusted R-squared & 0.556990 & S.D. dependent var & 34208.52 \\
S.E. of regression & 22768.85 & Akaike info criterion & 22.95537 \\
Sum squared resid & $1.87 \mathrm{E}+10$ & Schwarz criterion & 23.04156 \\
Log-likelihood & -434.1520 & Hannan-Quinn criter. & 22.98604 \\
F-statistic & 47.51956 & Durbin-Watson stat & 0.845828 \\
Prob(F-statistic) & 0.000000 & & & \\
& & & & \\
\end{tabular}


African Journal of Economics and Sustainable Development

ISSN: 2689-5080

Volume 4, Issue 3, 2021 (pp. 23-49)

\section{GEE@ LEVEL}

Null Hypothesis: GEE has a unit root

Exogenous: Constant

Lag Length: 1 (Fixed)

t-Statistic Prob.*

\begin{tabular}{lcrr} 
Augmented Dickey-Fuller test statistic & 0.161719 & 0.9664 \\
\hline Test critical values: & 1\% level & -3.615588 & \\
& 5\% level & -2.941145 & \\
& $10 \%$ level & -2.609066 &
\end{tabular}

*MacKinnon (1996) one-sided p-values.

Augmented Dickey-Fuller Test Equation

Dependent Variable: D(GEE)

Method: Least Squares

Date: 03/12/20 Time: $16: 37$

Sample (adjusted): 19822019

Included observations: 38 after adjustments

\begin{tabular}{lrlrc}
\hline \multicolumn{1}{c}{ Variable } & Coefficient & Std. Error & t-Statistic & Prob. \\
& & & & \\
\hline & & & & \\
GEE(-1) & 0.008187 & 0.050626 & 0.161719 & 0.8725 \\
D(GEE(-1)) & -0.456948 & 0.156087 & -2.927519 & 0.0060 \\
C & 10842.55 & 7894.636 & 1.373407 & 0.1784 \\
& & & & \\
\hline & & & \\
R-squared & 0.203276 & Mean dependent var & 8004.034 \\
Adjusted R-squared & 0.157749 & S.D. dependent var & 39867.13 \\
S.E. of regression & 36587.74 & Akaike info criterion & 23.92847 \\
Sum squared resid & $4.69 \mathrm{E}+10$ & Schwarz criterion & 24.05775 \\
Log-likelihood & -451.6409 & Hannan-Quinn criter. & 23.97447 \\
F-statistic & 4.464959 & Durbin-Watson stat & 2.210105 \\
Prob(F-statistic) & 0.018745 & & \\
& & & \\
\hline
\end{tabular}


African Journal of Economics and Sustainable Development

ISSN: 2689-5080

Volume 4, Issue 3, 2021 (pp. 23-49)

GEE @ $1^{\text {ST }}$ DIFF.

Null Hypothesis: D(GEE) has a unit root

Exogenous: Constant

Lag Length: 1 (Fixed)

t-Statistic Prob.*

\begin{tabular}{llll} 
Augmented Dickey-Fuller test statistic & -6.275450 & 0.0000 \\
\hline Test critical values: & $1 \%$ level & -3.621023 & \\
& 5\% level & -2.943427 & \\
& $10 \%$ level & -2.610263 &
\end{tabular}

*MacKinnon (1996) one-sided p-values.

Augmented Dickey-Fuller Test Equation

Dependent Variable: D(GEE,2)

Method: Least Squares

Date: 03/12/20 Time: 16:37

Sample (adjusted): 19832019

Included observations: 37 after adjustments

\begin{tabular}{lrlrr}
\hline \multicolumn{1}{c}{ Variable } & Coefficient & Std. Error & t-Statistic & Prob. \\
& & & & \\
\hline & & & & \\
D(GEE(-1)) & -1.786314 & 0.284651 & -6.275450 & 0.0000 \\
D(GEE(-1),2) & 0.229966 & 0.166997 & 1.377070 & 0.1775 \\
& 14759.68 & 6385.855 & 2.311309 & 0.0270 \\
& & & & \\
\hline & & & \\
R-squared & 0.740210 & Mean dependent var & -134.3378 \\
Adjusted R-squared & 0.724928 & S.D. dependent var & 68805.59 \\
S.E. of regression & 36086.65 & Akaike info criterion & 23.90284 \\
Sum squared resid & $4.43 E+10$ & Schwarz criterion & 24.03345 \\
Log-likelihood & -439.2025 & Hannan-Quinn criter. & 23.94889 \\
F-statistic & 48.43751 & Durbin-Watson stat & 1.984510 \\
Prob(F-statistic) & 0.000000 & & \\
& & & \\
\hline
\end{tabular}


African Journal of Economics and Sustainable Development

ISSN: 2689-5080

Volume 4, Issue 3, 2021 (pp. 23-49)

\section{GEH @ LEVEL}

Null Hypothesis: GEH has a unit root

Exogenous: Constant

Lag Length: 0 (Automatic - based on SIC, maxlag=9)

\section{t-Statistic Prob.*}

\begin{tabular}{lccc} 
Augmented Dickey-Fuller test statistic & -0.569587 & 0.8659 \\
\hline Test critical values: & 1\% level & -3.610453 & \\
& $5 \%$ level & -2.938987 & \\
& $10 \%$ level & -2.607932 &
\end{tabular}

*MacKinnon (1996) one-sided p-values.

Augmented Dickey-Fuller Test Equation

Dependent Variable: D(GEH)

Method: Least Squares

Date: 03/12/20 Time: $16: 38$

Sample (adjusted): 19812019

Included observations: 39 after adjustments

\begin{tabular}{lrlrc}
\hline \multicolumn{1}{c}{ Variable } & Coefficient & Std. Error & t-Statistic & Prob. \\
& & & & \\
\hline & & & & \\
GEH(-1) & -0.022817 & 0.040059 & -0.569587 & 0.5724 \\
\multicolumn{1}{c}{ C } & 3837.021 & 2713.689 & 1.413951 & 0.1657 \\
& & & & \\
\hline & & & \\
R-squared & 0.008692 & Mean dependent var & 2770.274 \\
Adjusted R-squared & -0.018100 & S.D. dependent var & 12154.51 \\
S.E. of regression & 12264.02 & Akaike info criterion & 21.71665 \\
Sum squared resid & $5.57 \mathrm{E}+09$ & Schwarz criterion & 21.80196 \\
Log-likelihood & -421.4746 & Hannan-Quinn criter. & 21.74726 \\
F-statistic & 0.324429 & Durbin-Watson stat & 2.128666 \\
Prob(F-statistic) & 0.572400 & & \\
& & & \\
\hline
\end{tabular}


African Journal of Economics and Sustainable Development

ISSN: 2689-5080

Volume 4, Issue 3, 2021 (pp. 23-49)

\section{GEH @ $1^{\text {ST }}$ DIFF.}

Null Hypothesis: $\mathrm{D}(\mathrm{GEH})$ has a unit root

Exogenous: Constant

Lag Length: 0 (Automatic - based on SIC, maxlag=9)

\section{t-Statistic Prob.*}

\begin{tabular}{lccc} 
Augmented Dickey-Fuller test statistic & -6.507465 & 0.0000 \\
\hline Test critical values: & $1 \%$ level & -3.615588 & \\
& 5\% level & -2.941145 & \\
& $10 \%$ level & -2.609066 &
\end{tabular}

*MacKinnon (1996) one-sided p-values.

Augmented Dickey-Fuller Test Equation

Dependent Variable: D(GEH,2)

Method: Least Squares

Date: 03/12/20 Time: $16: 38$

Sample (adjusted): 19822019

Included observations: 38 after adjustments

\begin{tabular}{lrlrr}
\hline \multicolumn{1}{c}{ Variable } & Coefficient & Std. Error & t-Statistic & Prob. \\
& & & & \\
\hline & & & & \\
\multicolumn{1}{c}{ (GEH(-1) } & -1.081002 & 0.166117 & -6.507465 & 0.0000 \\
& 3074.979 & 2072.198 & 1.483922 & 0.1465 \\
& & & & \\
\hline & & & \\
R-squared & 0.540506 & Mean dependent var & 0.547368 \\
Adjusted R-squared & 0.527743 & S.D. dependent var & 18098.48 \\
S.E. of regression & 12437.46 & Akaike info criterion & 21.74601 \\
Sum squared resid & $5.57 \mathrm{E}+09$ & Schwarz criterion & 21.83220 \\
Log-likelihood & -411.1742 & Hannan-Quinn criter. & 21.77667 \\
F-statistic & 42.34710 & Durbin-Watson stat & 2.037968 \\
Prob(F-statistic) & 0.000000 & & \\
& & & \\
\hline
\end{tabular}


African Journal of Economics and Sustainable Development

ISSN: 2689-5080

Volume 4, Issue 3, 2021 (pp. 23-49)

\section{HDI @ LEVEL}

Null Hypothesis: HDI has a unit root

Exogenous: Constant

Lag Length: 1 (Automatic - based on SIC, maxlag=9)

\section{t-Statistic Prob.*}

\begin{tabular}{lccc} 
Augmented Dickey-Fuller test statistic & -0.612546 & 0.8560 \\
\hline Test critical values: & 1\% level & -3.615588 & \\
& 5\% level & -2.941145 & \\
& $10 \%$ level & -2.609066 &
\end{tabular}

*MacKinnon (1996) one-sided p-values.

Augmented Dickey-Fuller Test Equation

Dependent Variable: D(HDI)

Method: Least Squares

Date: 03/12/20 Time: 16:39

Sample (adjusted): 19822019

Included observations: 38 after adjustments

\begin{tabular}{lrlrr}
\hline \multicolumn{1}{c}{ Variable } & Coefficient & Std. Error & t-Statistic & Prob. \\
& & & & \\
\hline & & & & \\
HDI(-1) & -0.049176 & 0.080281 & -0.612546 & 0.5441 \\
D(HDI(-1)) & -0.385970 & 0.159545 & -2.419193 & 0.0209 \\
\multicolumn{1}{c}{ C } & 0.026521 & 0.035673 & 0.743445 & 0.4622 \\
& & & & \\
\hline R-squared & 0.182624 & Mean dependent var & 0.003553 \\
Adjusted R-squared & 0.135917 & S.D. dependent var & 0.031329 \\
S.E. of regression & 0.029122 & Akaike info criterion & -4.159007 \\
Sum squared resid & 0.029683 & Schwarz criterion & -4.029724 \\
Log-likelihood & 82.02113 & Hannan-Quinn criter. & -4.113009 \\
F-statistic & 3.909983 & Durbin-Watson stat & 2.081611 \\
Prob(F-statistic) & 0.029335 & & \\
& & & \\
\hline
\end{tabular}


African Journal of Economics and Sustainable Development

ISSN: 2689-5080

Volume 4, Issue 3, 2021 (pp. 23-49)

\section{HDI @ $1^{\text {ST }}$ DIFF.}

Null Hypothesis: D(HDI) has a unit root

Exogenous: Constant

Lag Length: 0 (Automatic - based on SIC, maxlag=9)

\section{t-Statistic Prob.*}

\begin{tabular}{lccc} 
Augmented Dickey-Fuller test statistic & -9.380545 & 0.0000 \\
\hline Test critical values: & 1\% level & -3.615588 & \\
& 5\% level & -2.941145 & \\
& $10 \%$ level & -2.609066 &
\end{tabular}

*MacKinnon (1996) one-sided p-values.

Augmented Dickey-Fuller Test Equation

Dependent Variable: D(HDI,2)

Method: Least Squares

Date: 03/12/20 Time: 16:39

Sample (adjusted): 19822019

Included observations: 38 after adjustments

\begin{tabular}{lrlrr}
\hline \multicolumn{1}{c}{ Variable } & Coefficient & Std. Error & t-Statistic & Prob. \\
& & & & \\
\hline \multicolumn{1}{c}{ D(HDI(-1)) } & -1.415280 & 0.150874 & -9.380545 & 0.0000 \\
\multicolumn{1}{c}{ C } & 0.004864 & 0.004707 & 1.033326 & 0.3083 \\
& & & \\
\hline & & & \\
R-squared & 0.709665 & Mean dependent var & 0.000395 \\
Adjusted R-squared & 0.701600 & S.D. dependent var & 0.052846 \\
S.E. of regression & 0.028868 & Akaike info criterion & -4.200975 \\
Sum squared resid & 0.030001 & Schwarz criterion & -4.114786 \\
Log-likelihood & 81.81853 & Hannan-Quinn criter. & -4.170310 \\
F-statistic & 87.99463 & Durbin-Watson stat & 2.108469 \\
Prob(F-statistic) & 0.000000 & & \\
& & & \\
& & & \\
\end{tabular}


African Journal of Economics and Sustainable Development

ISSN: 2689-5080

Volume 4, Issue 3, 2021 (pp. 23-49)

\section{COINTEGRATION TEST RESULT}

Date: 03/12/20 Time: $16: 40$

Sample (adjusted): 19822019

Included observations: 38 after adjustments

Trend assumption: Quadratic deterministic trend

Series: RGDP GEE GEH HDI

Lags interval (in first differences): 1 to 1

Unrestricted Cointegration Rank Test (Trace)

\begin{tabular}{ccccc}
\hline $\begin{array}{c}\text { Hypothesized } \\
\text { No. of CE(s) }\end{array}$ & Eigenvalue & $\begin{array}{c}\text { Trace } \\
\text { Statistic }\end{array}$ & $\begin{array}{c}0.05 \\
\text { Critical Value }\end{array}$ & Prob.** \\
\hline & & & & \\
\hline None $*$ & 0.608559 & 75.28970 & 55.24578 & 0.0003 \\
At most 1* & 0.406333 & 39.64876 & 35.01090 & 0.0149 \\
At most 2* & 0.269912 & 19.83417 & 18.39771 & 0.0313 \\
At most 3* & 0.187274 & 7.879740 & 3.841466 & 0.0050 \\
& & & & \\
\hline
\end{tabular}

Trace test indicates 4 cointegrating eqn(s) at the 0.05 level

* denotes rejection of the hypothesis at the 0.05 level

**MacKinnon-Haug-Michelis (1999) p-values

Unrestricted Cointegration Rank Test (Maximum Eigenvalue)

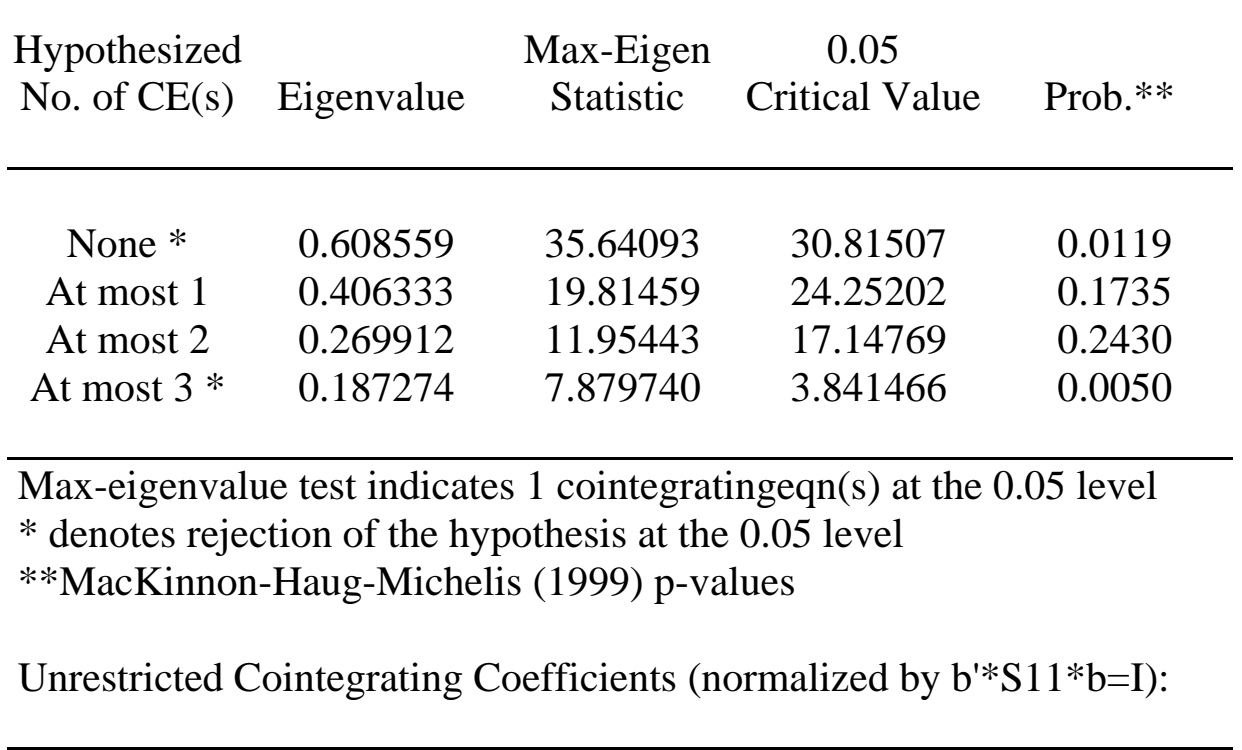


African Journal of Economics and Sustainable Development ISSN: 2689-5080

Volume 4, Issue 3, 2021 (pp. 23-49)

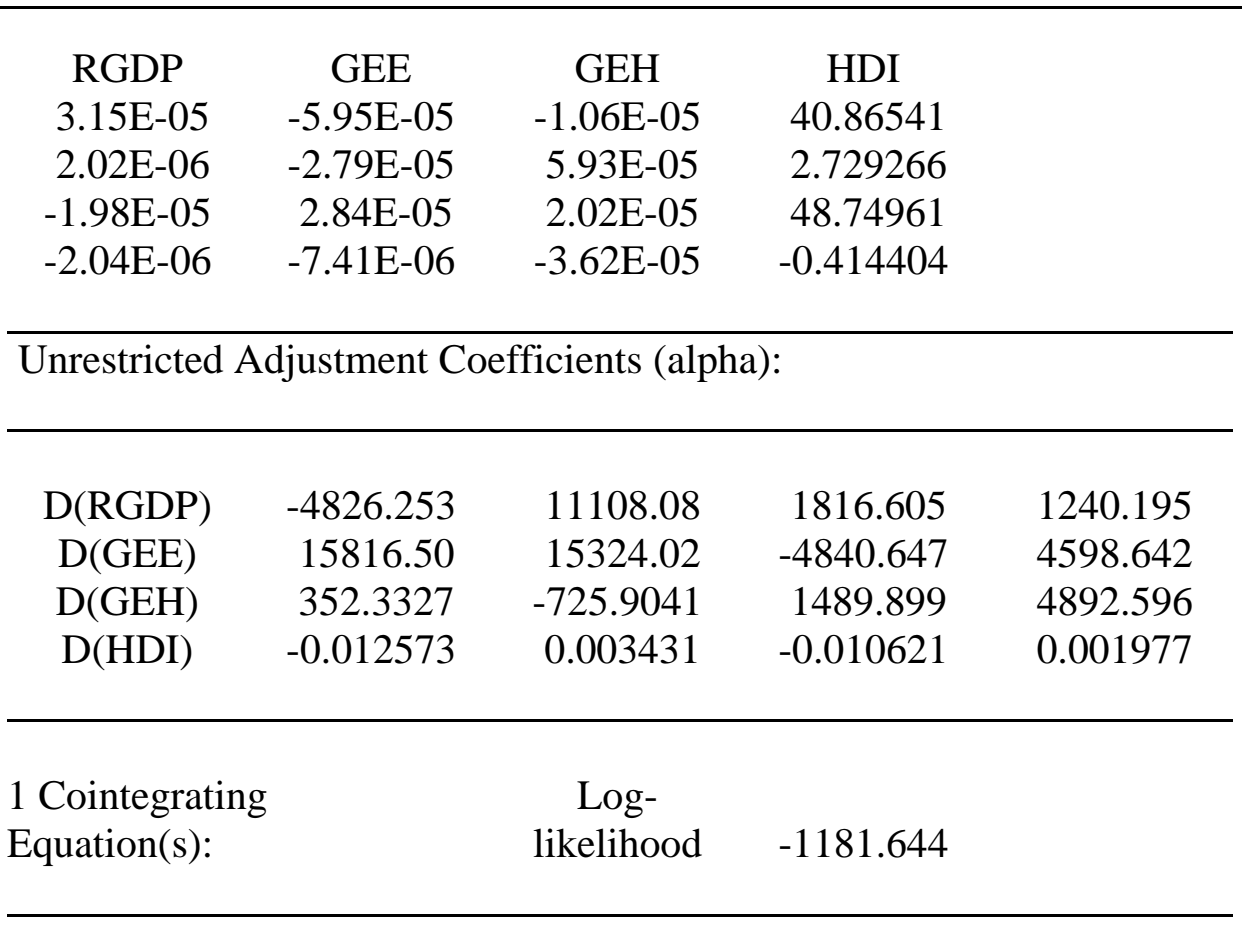

Normalized cointegrating coefficients (standard error in parentheses)

$\begin{array}{cccc}\text { RGDP } & \text { GEE } & \text { GEH } & \text { HDI } \\ 1.000000 & -1.890045 & -0.337915 & 1297737 . \\ & (0.12697) & (0.32788) & (288444 .)\end{array}$

Adjustment coefficients (standard error in parentheses)

$\begin{array}{cc}\mathrm{D}(\mathrm{RGDP}) & -0.151977 \\ & (0.10415) \\ \mathrm{D}(\mathrm{GEE}) & 0.498058 \\ & (0.17327) \\ \mathrm{D}(\mathrm{GEH}) & 0.011095 \\ & (0.06630) \\ \mathrm{D}(\mathrm{HDI}) & -3.96 \mathrm{E}-07 \\ & (1.3 \mathrm{E}-07)\end{array}$

$\begin{array}{lcl}2 \text { Cointegrating } & \text { Log- } & \\ \text { Equation(s): } & \text { likelihood } & -1171.737\end{array}$

\begin{tabular}{cccc}
\hline Normalized cointegrating coefficients (standard error in p \\
RGDP & GEE & GEH & HDI \\
1.000000 & 0.000000 & -5.043331 & 1289330. \\
& & $(1.04763)$ & $(1071865)$ \\
0.000000 & 1.000000 & -2.489579 & -4448.250 \\
& & $(0.52975)$ & $(542008)$.
\end{tabular}


African Journal of Economics and Sustainable Development ISSN: 2689-5080

Volume 4, Issue 3, 2021 (pp. 23-49)

\begin{tabular}{|c|c|c|c|}
\hline \multicolumn{4}{|c|}{ Adjustment coefficients (standard error in parentheses) } \\
\hline \multirow[t]{2}{*}{$\mathrm{D}(\mathrm{RGDP})$} & -0.129533 & -0.022690 & \\
\hline & $(0.08323)$ & $(0.17339)$ & \\
\hline \multirow[t]{2}{*}{$\mathrm{D}(\mathrm{GEE})$} & 0.529020 & -1.368917 & \\
\hline & $(0.15034)$ & $(0.31319)$ & \\
\hline \multirow[t]{2}{*}{$\mathrm{D}(\mathrm{GEH})$} & 0.009628 & -0.000716 & \\
\hline & $(0.06631)$ & $(0.13813)$ & \\
\hline \multirow[t]{2}{*}{$\mathrm{D}(\mathrm{HDI})$} & $-3.89 \mathrm{E}-07$ & $6.53 \mathrm{E}-07$ & \\
\hline & $(1.3 \mathrm{E}-07)$ & $(2.8 \mathrm{E}-07)$ & \\
\hline \multicolumn{2}{|c|}{3 Cointegrating } & Log- & \\
\hline \multicolumn{2}{|c|}{ Equation(s): } & likelihood & -1165.760 \\
\hline
\end{tabular}

Normalized cointegrating coefficients (standard error in parentheses)

$\begin{array}{cccc}\text { RGDP } & \text { GEE } & \text { GEH } & \text { HDI } \\ 1.000000 & 0.000000 & 0.000000 & -42011671 \\ & & & (1.1 \mathrm{E}+07) \\ 0.000000 & 1.000000 & 0.000000 & -21379459 \\ & & & (5410498) \\ 0.000000 & 0.000000 & 1.000000 & -8585794 . \\ & & & (2220469)\end{array}$

Adjustment coefficients (standard error in parentheses)

$\begin{array}{lccc}\mathrm{D}(\mathrm{RGDP}) & -0.165448 & 0.028970 & 0.746551 \\ & (0.09747) & (0.18747) & (0.16630) \\ \mathrm{D}(\mathrm{GEE}) & 0.624722 & -1.506574 & 0.641983 \\ & (0.17444) & (0.33551) & (0.29763) \\ \mathrm{D}(\mathrm{GEH}) & -0.019828 & 0.041653 & -0.016607 \\ & (0.07761) & (0.14928) & (0.13242) \\ \mathrm{D}(\mathrm{HDI}) & -1.79 \mathrm{E}-07 & 3.51 \mathrm{E}-07 & 1.22 \mathrm{E}-07 \\ & (1.4 \mathrm{E}-07) & (2.7 \mathrm{E}-07) & (2.4 \mathrm{E}-07)\end{array}$


African Journal of Economics and Sustainable Development

ISSN: 2689-5080

Volume 4, Issue 3, 2021 (pp. 23-49)

Dependent Variable: RGDP

Method: Least Squares

Date: 03/12/20 Time: 16:41

Sample: 19802019

Included observations: 40

\begin{tabular}{cclcc}
\hline \multicolumn{1}{c}{ Variable } & Coefficient & Std. Error & t-Statistic & Prob. \\
& & & & \\
\hline & & & & \\
GEE & 42094.42 & 140106.9 & 0.300445 & 0.7656 \\
GEH & 1.753221 & 0.225235 & 7.783958 & 0.0000 \\
HDI & 1.114968 & 0.543112 & 2.052926 & 0.0474 \\
& 446954.1 & 355812.7 & 1.256150 & 0.2172 \\
& & & & \\
R-squared & 0.959117 & Mean dependent var & 484695.7 \\
Adjusted R-squared & 0.955710 & S.D. dependent var & 302400.1 \\
S.E. of regression & 63640.64 & Akaike info criterion & 25.05453 \\
Sum squared resid & $1.46 E+11$ & Schwarz criterion & 25.22342 \\
Log-likelihood & -497.0906 & Hannan-Quinn criter. & 25.11560 \\
F-statistic & 281.5204 & Durbin-Watson stat & 1.486896 \\
Prob(F-statistic) & 0.000000 & & \\
& & & \\
\hline
\end{tabular}

Dependent Variable: LOG(RGDP)

Method: Least Squares

Date: 03/12/20 Time: 16:41

Sample: 19802019

Included observations: 40

\begin{tabular}{lrlrc}
\hline \multicolumn{1}{c}{ Variable } & Coefficient & Std. Error & t-Statistic & Prob. \\
& & & & \\
\hline \multicolumn{1}{c}{ C } & 9.909764 & 1.695061 & 5.846257 & 0.0000 \\
LOG(GEE) & 0.246547 & 0.238484 & 1.033807 & 0.3081 \\
LOG(GEH) & 0.033577 & 0.190998 & 0.175798 & 0.8614 \\
& -0.216782 & 1.085356 & -0.199734 & 0.8428 \\
& & & & \\
R-squared & 0.755342 & Mean dependent var & 12.87444 \\
Adjusted R-squared & 0.734953 & S.D. dependent var & 0.720022 \\
S.E. of regression & 0.370686 & Akaike info criterion & 0.947718 \\
Sum squared resid & 4.946701 & Schwarz criterion & 1.116606 \\
Log-likelihood & -14.95437 & Hannan-Quinn criter. & 1.008783 \\
F-statistic & 37.04799 & Durbin-Watson stat & 0.858131 \\
Prob(F-statistic) & 0.000000 & & & \\
& & & &
\end{tabular}




\section{Over Parameterized Error Correction Mechanism}

Dependent Variable: D(RGDP)

Method: Least Squares

Date: 03/12/20 Time: 16:44

Sample (adjusted): 19842019

Included observations: 36 after adjustments

\begin{tabular}{crrrr}
\hline Variable & Coefficient & Std. Error & t-Statistic & Prob. \\
& & & & \\
\hline C & 10377.41 & 5553.513 & 1.868622 & 0.0772 \\
D(RGDP(-1)) & 0.577824 & 0.215527 & 2.680989 & 0.0148 \\
D(RGDP(-2)) & -0.026058 & 0.227740 & -0.114419 & 0.9101 \\
D(RGDP(-3)) & -0.118756 & 0.095952 & -1.237655 & 0.2309 \\
D(GEE) & 0.228440 & 0.083074 & 2.749846 & 0.0127 \\
D(GEE(-1)) & 0.268309 & 0.112845 & 2.377670 & 0.0281 \\
D(GEE(-2)) & 0.099602 & 0.118160 & 0.842943 & 0.4097 \\
D(GEE(-3)) & 0.180382 & 0.097987 & 1.840869 & 0.0813 \\
D(GEH) & -0.321865 & 0.312147 & -1.031133 & 0.3154 \\
D(GEH(-1)) & 0.095863 & 0.310179 & 0.309055 & 0.7606 \\
D(GEH(-2)) & -0.292853 & 0.314098 & -0.932360 & 0.3628 \\
D(GEH(-3)) & 0.091282 & 0.269260 & 0.339011 & 0.7383 \\
D(HDI) & -2210.254 & 118670.1 & -0.018625 & 0.9853 \\
D(HDI(-1)) & -178433.1 & 152694.4 & -1.168563 & 0.2570 \\
D(HDI(-2)) & -192670.6 & 142319.8 & -1.353786 & 0.1917 \\
D(HDI(-3)) & -28541.34 & 99122.94 & -0.287939 & 0.7765 \\
ECM(-1) & -26004.37 & 19927.32 & -1.304960 & 0.2075 \\
& & & & \\
\hline
\end{tabular}

R-squared

0.777192 Mean dependent var 22019.27

Adjusted R-squared

0.589565

S.D. dependent var

23518.47

S.E. of regression

15067.16

Akaike info criterion 22.38379

Sum squared resid

$4.31 \mathrm{E}+09$

Schwarz criterion

23.13156

Log-likelihood

$-385.9082$

Hannan-Quinn criter. 22.64478

F-statistic

4.142210

Durbin-Watson stat

1.934881

Prob(F-statistic)

0.002007 
African Journal of Economics and Sustainable Development

ISSN: 2689-5080

Volume 4, Issue 3, 2021 (pp. 23-49)

www.abjournals.org

\section{Parsimonious Error Correction Mechanism Result}

Dependent Variable: D(RGDP)

Method: Least Squares

Date: 03/12/20 Time: 16:46

Sample (adjusted): 19842019

Included observations: 36 after adjustments

\begin{tabular}{|c|c|c|c|c|}
\hline Variable & Coefficient & Std. Error & t-Statistic & Prob. \\
\hline $\mathrm{C}$ & 7959.825 & 4191.029 & 1.899253 & 0.0679 \\
\hline $\mathrm{D}(\mathrm{RGDP}(-1))$ & 0.528735 & 0.178495 & 2.962186 & 0.0062 \\
\hline $\mathrm{D}(\mathrm{RGDP}(-2))$ & 0.140320 & 0.193712 & 0.724371 & 0.4748 \\
\hline $\mathrm{D}(\mathrm{RGDP}(-3))$ & -0.036200 & 0.085917 & -0.421331 & 0.6767 \\
\hline $\mathrm{D}(\operatorname{GEE}(-3))$ & 0.092904 & 0.075398 & 189 & 0.2281 \\
\hline $\mathrm{D}(\mathrm{GEH}(-3))$ & 0.113793 & 0.235602 & 0.482986 & 0.6329 \\
\hline $\mathrm{D}(\mathrm{HDI}(-3))$ & 57273.04 & 87333.92 & 0.655794 & 0.5173 \\
\hline $\operatorname{ECM}(-1)$ & -25233.51 & 13438.78 & -1.877664 & 0.0709 \\
\hline R-squared & 13 & \multicolumn{2}{|c|}{ Mean dependent var } & 22019.27 \\
\hline Adjusted R-squared & 0.504141 & \multicolumn{2}{|c|}{ S.D. dependent var } & 23518.47 \\
\hline S.E. of regression & 16561.06 & \multicolumn{2}{|c|}{ Akaike info criterion } & 22.46063 \\
\hline Sum squared resid & 7.68E+09 & \multicolumn{2}{|c|}{ Schwarz criterion } & 22.81252 \\
\hline Log-likelihood & -396.2913 & \multirow{2}{*}{\multicolumn{2}{|c|}{$\begin{array}{l}\text { Hannan-Quinn criter. } \\
\text { Durbin-Watson stat }\end{array}$}} & 22.58345 \\
\hline F-statistic & 6.083513 & & & 1.846038 \\
\hline $\operatorname{Prob}(F-$-statistic $)$ & 0.000223 & & & \\
\hline
\end{tabular}

\section{Normality Test Result}

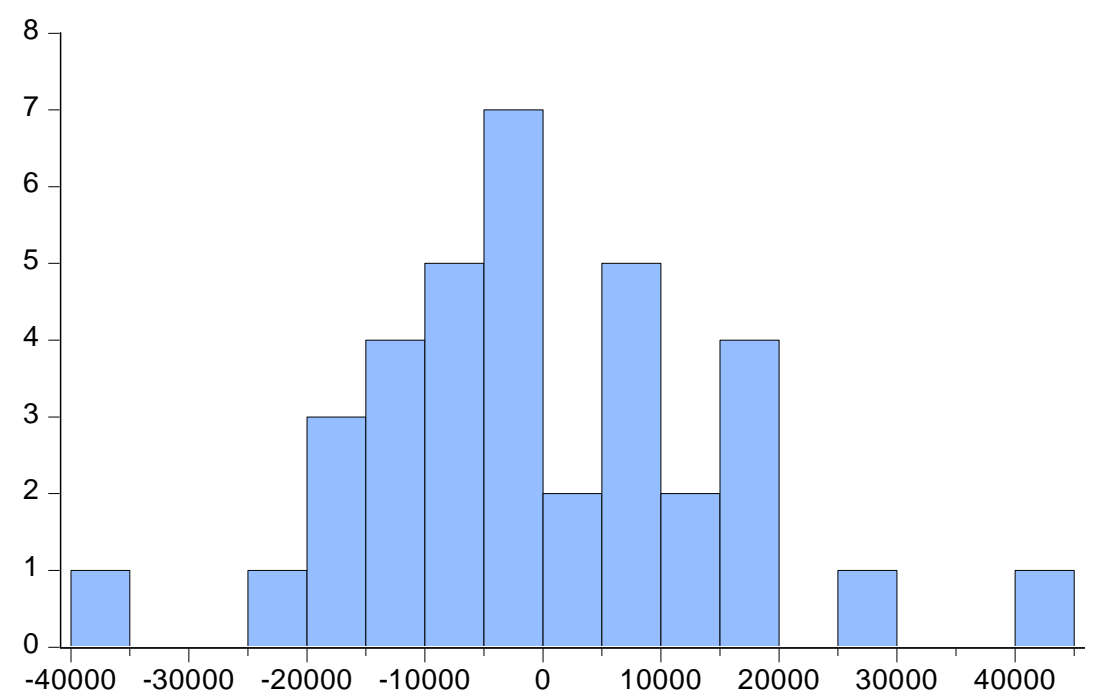

\begin{tabular}{lc}
\multicolumn{2}{l}{ Series: Residuals } \\
Sample 1984 2019 \\
Observations 36 \\
Mean & $1.95 \mathrm{e}-12$ \\
Median & -1026.044 \\
Maximum & 40220.47 \\
Minimum & -37052.67 \\
Std. Dev. & 14812.66 \\
Skewness & 0.250944 \\
Kurtosis & 3.655904 \\
& \\
Jarque-Bera & 1.023152 \\
Probability & 0.599550
\end{tabular}

